\title{
AMOR AL VECINO Y CUESTIONAMIENTOS A LA NACIÓN EN LA LITERATURA DEL SIGLO DIECINUEVE ${ }^{1}$
}

\author{
RODRIGO ANDRÉS \\ Universitat de Barcelona
}

La figura de "el vecino" es en sí misma interesante debido a que excede a la oposición binaria formada por amigo y enemigo, o por esa persona con la que me identifico, por un lado, y ese completo extraño al que tal vez vea como un Otro irreducible, por otro. El vecino, en cuanto figura que no pertence al espacio privado inmediato del círculo familiar y doméstico pero que, aun y así, está en el círculo de la proximidad física en la comunidad, es relevante por razones políticas y éticas. Este ensayo explora pasajes de pensadores como Hannah Arendt, Zygmunt Bauman, Maurice Blanchot, Judith Butler, Roberto Esposito, Sigmund Freud, Ernesto Laclau, Emmanuel Levinas, Kenneth Reinhard, Franz Rosenzweig, Eric Santner, Richard Sennett y Slavoj Žižek, entre otros, y glosa algunas de las posiciones en el debate sobre la aplicabilidad del precepto "ama a tu vecino como a ti mismo".

PALABRAS CLAVE: Vecino, literatura, ética, siglo XIX, nación, universalismo.

\section{Loving the Neighbor and Questioning the Nation in Nineteenth-century Literature}

The figure of the neighbor in itself is interesting as it lies beyond the binary opposition formed by friend and enemy, or by that person I identify with, on the one hand, and that complete stranger I may see as an irreducible Other, on the other. The neighbor, as a figure that does not belong to the immediate private space of the familial and domestic circle but who is still within the circle of physical proximity in the community, is relevant for political and for ethical reasons. This essay surveys passages by thinkers Hannah Arendt, Zygmunt Bauman, Maurice Blanchot, Judith Butler, Roberto Esposito, Sigmund Freud, Ernesto Laclau, Emmanuel Levinas, Kenneth Reinhard, Franz Rosenzweig, Eric Santner, Richard Sennett and Slavoj Žižek, among others, sampling some positions in the debate about the practicality of the precept "Love your neighbor as yourself".

KEY WORDS: Neighbor, literature, ethics, nineteenth century, nation, universalism.

\footnotetext{
${ }^{1}$ Este artículo se inscribe en el proyecto de investigación Literatura y comunidades: una visión desde el género (FEM 2011-23808, Ministerio de Economía y Competitividad. I.P: Marta Segarra Montaner, Centre Dona i Literatura, Universitat de Barcelona).
}

Andrés, Rodrigo (2014), "Amor al vecino y cuestionamientos a la nación en la literatura del siglo diecinueve", Lectora, 20: 15-46. ISSN: 1136-5781 D.O.I.: XXXXXXXXXX

Recepció: 1 de juny de 2014 - Acceptació: 15 de juliol de 2014 


\section{El mandato de amar al vecino}

El precepto de las enseñanzas cristianas "ama a tu vecino como a ti mismo" proviene de las antiguas doctrinas hebreas y tiene sus orígenes en el Levítico 19:18. Con su sentido de humor característico, Terry Eagleton afirma que "[e]1 mandato de amar a tu vecino no es un invento cristiano, sino que proviene del Libro de Levítico, del Antiguo Testamento. La gente no tuvo que esperar hasta la llegada de un desconocido profeta judío del siglo I, que probablemente tenía menos tirón de masas que su mentor Juan Bautista, para empezar a ser amables los unos con los otros"2 (Eagleton, 2004: 146). El mandato es ciertamente central en el Talmud y, como nos recuerda Zygmunt Bauman, "[c]uando un potencial candidato a converso desafió al sabio talmúdico, el rabino Hillel, a que explicara las enseñanzas de Dios en el tiempo en que el desafiante se podía mantener sobre un pie, aquel ofreció 'ama a tu vecino como a ti mismo' como la única y, sin embargo, completa respuesta que engloba a la totalidad de los mandatos de $\operatorname{Dios}^{\prime 3}$ (2003: 78). La importancia del mandamiento dentro del cristianismo se debe, sobre todo, a la Epístola a los romanos 13, en la que, como hiciera Hillel, el apóstol San Pablo también reduce todos los mandamientos bíblicos a uno solo: "Amarás a tu vecino como a ti mismo". Así pues, como subraya Reinhard, "[...] tanto en la doxología judía como en la cristiana, el amor a Dios está convencionalmente emparejado con el amor al vecino, como dos imperativos o principios ético-teológicos, esencialmente unidos" 4 (Reinhard, 2006: 12). Pero es también innegable que la relevancia de la máxima "ama al vecino" transciende la religiosidad $\mathrm{y}$ es uno de los ejes del pensamiento secular $-\mathrm{o}$ incluso "postsecular"-, especialmente en los siglos XIX, XX y XXI. Eric L. Santner, tras analizar las lecturas que de la figura del vecino en esa máxima religiosa llevan a cabo los pensadores Sigmund Freud, Franz Rosenzweig y Walter Benjamin, afirma:

\footnotetext{
2 "The injunction to love your neighbor is not a Christian invention, but stems from the Old Testament Book of Leviticus. People did not have to wait upon the arrival of an obscure firstcentury Jewish prophet, who was probably less of a crowd-puller than his mentor John the Baptist, in order to start being nice to each other". De aquí en adelante, todas las traducciones del inglés son del autor.

3 "When the Talmudic sage Rabbi Hillel was challenged by a prospective convert to explain God's teaching in the time the challenger could stand on one foot, he offered 'love thy neighbour as thyself as the only, yet complete, answer, encapsulating the totality of God's injunctions."

4 "in both Jewish and Christian doxology, love of God is conventionally paired with love of the neighbour, as two essentially linked imperatives or theological-ethical principles."
} 
No necesitamos [...] a Dios para las cosas divinas, sino para estar bien atentos a las cosas seculares. [...] no se trata de escoger una de estas opciones por encima de las otras - por ejemplo, la freudiana por encima de la rosenzweigiana o de la benjaminiana- sino de pensar en ellas conjuntamente e intentar valorar los modos en los que cada una ofrece recursos para profundizar en nuestra comprensión de las otras. Más que una forma de pensamiento religioso, me gustaría considerar que este es un primer paso tentativo en el camino de lo que podríamos modestamente denominar pensamiento postsecular. ${ }^{5}$ (Santner, 2006: 133)

\section{El interés teórico tanto por la figura del vecino como por el precepto de amarle}

El vecino es alguien que no pertenece al espacio privado del círculo familiar y doméstico, pero que se encuentra en el anillo inmediato de proximidad física dentro de la comunidad. El espacio resultante de/en esas paradójicas proximidad y distancia necesarias en la relación del sujeto con el vecino es un ámbito rico para el análisis de lo intersubjetivo, especialmente si tenemos en cuenta las nociones arendtianas de los requisitos espaciales para la construcción y la acción política. Como apunta Kenneth Reinhard al respecto, al argumentar que la desaparición del espacio hasta el vecino marca la disolución de la política en la modernidad Arendt ${ }^{6}$ implica que "el vecino es una categoría que preocupa de manera esencial a la teoría política y no meramente una función de la ética; se trata de una categoría de relación social crucial para el mantenimiento de la esfera de lo político como tal"7 (Reinhard, 2006: 26). El vecino, así pues, resulta especialmente interesante porque está más allá de lo familiar y dentro del espacio de la ética, tanto en una relación de a dos (en el yo y mi obligación para con el vecino, de Emmanuel Levinas), como en el espacio "abierto" (en términos de Alain Badiou) a/en la política.

\footnotetext{
5 "We don't [...] need God for the sake of divine things but for the sake of proper attentiveness to secular things. [...] it is not a matter of choosing one of these options over the others - say, the Freudian over the Rosenzweigian or Benjaminian - but rather of thinking them together and trying to appreciate the ways in which each one provides a resource for deepening our grasp of the others. Rather than a form of religious thinking, I'd like to consider this to be a first, tentative step along a path of what we might more modestly call postsecular thinking."

${ }^{6}$ En el totalitarismo el fracaso de las relaciones sociales se debe a la desaparición del espacio entre las personas necesario para que pueda producirse el pensamiento con uno mismo como proceso discursivo social.

7 "the neighbor is a category of essential concern for political theory and not merely a function of ethics, a category of social relation crucial to the maintenance of the sphere of the political as such."
} 
En cuanto al precepto de amar al "vecino" como a uno mismo, ${ }^{8}$ la principal dificultad que presenta es, sin duda, su implementación. Teóricos y no teóricos, pensadores judíos, cristianos, agnósticos y ateos coinciden en subrayar la imposibilidad de cumplirlo a rajatabla o, simplemente, de intentar ponerlo en práctica. A pesar de ello, para algunos pensadores, el precepto, si bien impracticable, puede resultar productivo en tanto que ideal al que acercarse.

De hecho, la figura del vecino y la obligación de amarle pueden hacer brotar en nosotros nuestras mejores cualidades humanitarias e incluso pueden convertirse en la prueba máxima de nuestra humanidad. Para Zygmunt Bauman, por ejemplo,

[a]ceptar esa orden [la de amar a tu vecino como a ti mismo] es un acto de confianza ciega; un acto de confianza ciega decisivo a través del cual un ser humano rompe con el caparazón de sus instintos, necesidades y predilecciones "naturales", se distancia y se pone en contra de la naturaleza y se convierte en el ser "innatural" que, a diferencia de las bestias [...] somos los seres humanos. Aceptar el precepto de amar al vecino es el acto de nacimiento de la humanidad. Todas las demás rutinas de la cohabitación humana, así como sus reglas prediseñadas o descubiertas retrospectivamente, configuran sólo una lista (nunca completa) de notas a pie de página a ese precepto. Si este precepto fuese ignorado o eliminado, no habría nadie que hiciera esa lista o que evaluara cuan completa es. ${ }^{9}$ (Bauman, 2003: 78)

Para Bauman, así pues, el precepto es esencial puesto que determina tanto la supervivencia del humanitarismo de la especie como la de la propia humanidad:

Amar al vecino puede requerir un acto de fe ciega; el resultado, sin embargo, es el acto de nacimiento de la humanidad. También es el paso

\footnotetext{
${ }^{8} \mathrm{Al}$ utilizar "el vecino" en género masculino y entrecomillado subrayamos intencionalmente la falta de especificidad de sexo y/o género con el que el concepto se ha utilizado en textos religiosos, filosóficos, legales y populares. Las contribuciones a este dossier, como veremos, sí demuestran la especificidad de sexo y de género en la corpo-realidad de la vecina, de el vecino, dentro, a su vez, de otras especificidades, tales como la clase social, la "raza", la etnia, la migración, en las diversas literaturas "nacionales" de occidente.

9 "Accepting such a command [i.e. love thy neighbor as thyself] is a leap of faith; a decisive leap, through which a human being breaks out of the carapace of "natural" drives, urges and predilections, takes a position away from and against nature, and turns into the "unnatural" being that, unlike the beasts [...] humans are. Accepting the precept of loving one's neighbor is the birth act of humanity. All other routines of human cohabitation, as well as their predesigned or retrospectively discovered rules, are but a (never complete) list of footnotes to that precept. Were this precept to be ignored or thrown away, there would be no one to make that list or ponder its completeness."
} 
transcendental desde el instinto de supervivencia a la moralidad. Este es un paso que hace de la moralidad parte, quizás una conditio sine qua non, de la supervivencia. Con ese ingrediente, la supervivencia de un humano/una humana se convierte en la supervivencia de la humanidad en el ser humano. ${ }^{10}(2003: 78)$

Otra de las razones que hacen de este precepto religioso y secular un instrumento especialmente productivo en el plano teórico es, como señala Bárbara Arizti, su potencialidad de transcender e incluso de llegar a "romper la dicotomía amigo/enemigo sobre la que la teología política tradicional está construida"11 (2013). Esta es una potencialidad destacada también por Kenneth Reinhard, quien sostiene que la figura del vecino "materializa la división incierta entre amigo/familia/yo y enemigo/extraño/otro"12 (Reinhard, 2006: 18). Reinhard, interesado en una teología política del vecino, propone "un modo de relación política que no estaría basada en la pareja amigo-enemigo, sino en el vecino como tercer término, un tercer término de algún modo ignorado por la oposición binaria de Schmitt, pero que no es menos central al discurso religioso, a la sociabilidad, y a la teología política [...]"13 (Reinhard, 2006: 13). En su análisis de los fundamentos teológicos de la teoría política, Reinhard argumenta que "[s]olo a base de considerar los principios de amor a Dios y amor al vecino juntos, como dos mitades de un mismo pensamiento, como es el caso tanto en la doctrina judía como en la cristiana, podemos empezar a imaginar otras posibilidades de organización social y subjetiva" ${ }^{14}$ (Reinhard, 2006: 14). Reinhard expone que en La estrella de la redención (1921) Franz Rosenzweig sostenía que el amor al vecino es el vehículo para la redención del mundo, redención no abstracta y futurible, sino que tiene lugar en el momento presente y en la cercanía misma del vecino: "El vínculo de la unión consumada y redentora del hombre con el mundo debe empezar con el vecino y, lo que es más, solamente con el

\footnotetext{
10 "Loving thy neighbor may require a leap of faith; the result, though, is the birth act of humanity. It is also the fateful passage from the instinct of survival to morality. This is a passage that renders morality a part, perhaps a conditio sine qua non, of survival. With that ingredient, survival of a human becomes the survival of humanity in the human."

11 "breaking the dichotomy friend/enemy on which traditional political theology is built."

12 "materializes the uncertain division between the friend/family/self and the enemy/stranger/other."

13 "a mode of political relation that would not be based on the friend-enemy couple, but on the neighbour as a third term, one that is obscured by Schmitt's binary opposition, but that is no less central to religious discourse, sociality, and political theology."

14 "It is only by considering the principles of love of God and love of neighbour together, as two halves of the same thought, as is the case in both Jewish and Christian doctrine, that we can begin to imagine other possibilities for social and subjective organization."
} 
vecino, el inmediato más próximo"15 (Rosenzweig, 1985: 236). Según Reinhard, "[p]ara Rosenzweig, el amor al vecino no es meramente el primer paso en el camino hacia la redención, la buena acción que puede ayudar a hacer del mundo un lugar mejor en un futuro hipotético, sino su realización ahora, la producción inmanente de sus condiciones transcendentales"16 (Reinhard, 2006: 21).

En el plano sociológico, numerosos teóricos consideran que amar al vecino repercute en beneficio no solo del amado, sino también del que ama ya que, gracias a la exposición al vecino y al interés por él en su diferencia, quien ama puede obtener una fuente inestimable de aprendizaje. Resumimos esta visión a través, una vez más, de Zygmunt Bauman, cuya obra se caracteriza con frecuencia por su esperanzado optimismo: "Vivir [...] significa vivir en compañía, en compañía de extranjeros. Nunca dejaremos de ser extranjeros: nos mantendremos como tales, sin interés en actuar, pero por ser vecinos los unos de los otros, destinados a enriquecernos recíprocamente" (Bauman, 2006: 61).

\section{Objeciones teóricas al mandato}

Sin embargo, son también numerosas las objeciones que filósofos, antropólogos, sociólogos y politólogos, entre tantos otros, han presentado al precepto en relación con su aplicabilidad, con su oportunidad o incluso con su bondad. Entre las brechas y falencias del precepto señaladas con mayor claridad y frecuencia escogemos destacar las siguientes:

1. El mandato no parece dejar claro si cumplirlo supone un intento de acercamiento al vecino en $s u$ realidad - y alteridad irrefutable - o responde a una voluntad de apropiación del vecino a la nuestra. Bárbara Arizti señala certeramente un fragmento del volumen The Neighbor en el que sus editores, Slavoj Žižek, Eric L. Santner y Kenneth Reinhard, se plantean: “¿debemos entender al vecino como una extensión de la categoría del yo, de lo familiar y del amigo, es decir como alguien como yo a quien estoy obligado a dar tratamiento preferencial; o supone la inclusión del otro en mi círculo de responsabilidad, extendiéndose hasta el desconocido, incluso hasta el enemigo?” Žižek, Santner y Reinhard complementan esta pregunta con la consiguiente " ¿nos pide ese mandamiento que expandamos el ámbito de nuestras identificaciones o nos exige que nos acerquemos, que nos hagamos responsables de una alteridad que se

\footnotetext{
15 "The bond of the consummate and redemptive bonding of man and the world is to begin with the neighbour and ever more only the neighbour, the well nigh-nighest."

16 "For Rosenzweig, love of the neighbour is not merely the first step on the path to redemption, the good deed that might help make the world a better place in some hypothetical future, but its realization now, the immanent production of its transcendental conditions."
} 
mantiene radicalmente inasimilable?” (Žižek et al. 2009: 6-7, citados en Arizti 2013). ${ }^{17}$

2. En relación con esta cuestión, otra reflexión resulta oportuna, basada en la duda en torno a si "el vecino" en el mandato se corresponde con una persona real, recipiente específico de nuestro amor, o si en realidad representa una ocasión para ese amor. En teoría, el mandamiento podría considerar al vecino en su corpo-realidad, con su rostro. En palabras de Levinas, "El para-el-otro que responda al vecino, en la proximidad del vecino, es una responsabilidad que significa - u ordena - precisamente el rostro en su alteridad"18 (2008: 106) y que supone una obligación hacia el Otro que es infinita, sin preguntas sobre la reciprocidad. Se trata, para Levinas, de una relación asimétrica, de entrada, y de responsabilidad ilimitada e infinita. Levinas insiste en la unicidad del vecino, afirmando que esa unicidad supone "una responsabilidad que, sin duda, mantiene el secreto de la sociabilidad, cuya gravedad total - aunque sea en vano hasta el límite - se llama 'ama al vecino' - es decir, la posibilidad propia de la unicidad del ser único (más allá de la particularidad del individuo en un genus)"19 (Levinas, 2008: 110). A pesar de ello, varios teóricos plantean si al referirnos a "el vecino" no estamos tal vez olvidando su materialidad, su corporealidad, y ocupándonos sólo de una noción abstracta que sirve a un gesto, sea éste la caridad, la compasión o el amor. ¿Estamos hablando de amar al vecino o de amar al amor al vecino? ¿Amamos al vecino en cuanto vecino o en cuanto manifestación de la existencia de Dios? Según Richard A. Cohen, por ejemplo, Emmanuel Levinas concebiría al vecino de este segundo modo, es decir, como manifestación y vehículo de lo divino:

La aparición de Dios, así pues, no es la aparición de un conjunto de mandatos absolutos o de un texto privilegiado, ni es una revelación que abre los cielos, sino que es, en realidad, la excelencia misma de la ética, un mandado sin mandamientos, el amor al Otro antes que el amor a uno mismo, "el amor", como Levinas lo describe, recordando a Pascal, "sin concupiscencia". [...] Cuidar así al vecino más que a uno mismo,

\footnotetext{
17 "Is the neighbor understood as an extension of the category of the self, the familial, and the friend, that is, as someone like me whom I am obligated to give preferential treatment to; or does it imply the inclusion of the other into my circle or responsibility, extending to the stranger, even the enemy? [...] does the commandment call us to expand the range of our identifications or does it urge us to come closer, become answerable to, an alterity that remains radically inassimilable?"

18 "The for-the-other responsive to the neighbor, in the proximity of the neighbor, is a responsibility that signifies - or commands- precisely the face in its alterity."

19 "It is a responsibility that, without doubt, keeps the secret of sociality, whose total gravity be it in vain to the limit - is called 'love of the neighbor' - that is, the very possibility of the unicity of the unique one (beyond the particularity of the individual in a genus)."
} 
asumir responsabilidad por el Otro, la ética, y asumir las responsabilidades del Otro, la justicia, es entrar en una historia sagrada, más que en una historia ontológica o epistemológica. "La existencia de Dios", Levinas ha sostenido en una entrevista reciente, "es historia sagrada en sí misma, lo sagrado de la relación del hombre con el hombre a través de la cual Dios puede pasar" ${ }^{20}$ (Cohen, 2008: 26)

En este sentido, Richard Sennett argumenta convincentemente, apoyándose en la pregunta formulada por Hannah Arendt en 1929 sobre la naturaleza exacta de la caritas cristiana en un ensayo sobre San Agustín, que tal vez uno de los peligros radique en el hecho de obviar al vecino real y de convertirle (a él, a ella) en el instrumento, pasivo y sin agentividad, para un gesto propio, mío, ciego a su realidad:

San Agustín concebía el amor al vecino de un modo bastante diferente al de albergar buenos sentimientos hacia un vecino en particular. Por el contrario, el filósofo cristiano consideraba que "amo algo en él... que, en sí mismo, él no es”, tal y como Arendt parafrasea de las Confesiones de San Agustín. El vecino es alguien a quien deberíamos ver exclusivamente en relación con Dios, no en cuanto a persona en concreto. De nuevo en la elegante formulación de Arendt: "El cristiano puede amar a todas las personas porque cada una de ellas es tan sólo una ocasión... el enemigo e incluso el pecador... meras ocasiones para amar. En realidad, lo que se ama en este amar al vecino no es al vecino, sino al amor mismo."21 (Sennett, 2003: 138-139)

\footnotetext{
20 "The appearance of God, then, is not the appearance of a set of absolute rules or a privileged text, nor is it a revelation which opens the skies, it is, rather, the very excellence of ethics, command without commandments, the love for the Other prior to the love for oneself, 'love' as Levinas describes it, 'without concupiscence.' [...] Thus to care for one's neighbor more than oneself, to take on responsibility for the Other, ethics, and to take on the Other's responsibilities, justice, is to enter into a sacred rather than an ontological or epistemological history. 'The existence of God,' Levinas has said in a recent interview, 'is sacred history itself, the sacredness of man's relation to man through which God may pass."

21 "St. Augustine conceived of love for one's neighbor in a way quite foreign to harboring warm feelings for any particular neighbor. Instead the Christian philosopher believed that 'I love something in him... which, of himself, he is not,' as Arendt paraphrases from his Confessions. The neighbor is someone whom we should see only in relation to God, not as a particular person. Again in Arendt's elegant formulation: 'The Christian can love all people because each one is only an occasion,... the enemy and even the sinner... mere occasions for love. It is not really the neighbor who is loved in this love of neighbor - it is love itself." Agradezco a Laura López esta referencia.
} 
Esta paradójica eliminación del vecino en su realidad en el acto de amarle ha sido una constante en textos filosóficos y morales a lo largo de los siglos. Desde el momento en que Plutarco afirmó, por ejemplo, que "[d]eberíamos considerar a todos los seres humanos como nuestros conciudadanos y vecinos"22 (citado en Nussbaum, 1996: 7), la especificidad del vecino y de su proximidad, entre otros factores, queda subsumida en/por la abstracción de la universalidad. La eliminación de la realidad del vecino puede conllevar, así pues, la consiguiente eliminación de su subjetividad y de su agentividad. Según Slavoj Žižek,

[c]uando Freud y Lacan insisten en la naturaleza problemática del mandamiento básico judeo-cristiano de "amar a tu vecino," no están solo diciendo algo importante desde el punto de vista critico-ideológico estándar sobre como toda noción de universalidad está teñida por nuestros valores particulares $\mathrm{y}$, por lo tanto, implica exclusiones secretas; están diciendo algo mucho más importante sobre la incompatibilidad del Vecino con la misma dimensión de la universalidad. Lo que se resiste a la universalidad es la dimensión propiamente inhumana del Vecino. Es por este motivo que encontrarse a uno mismo en la posición del amado es tan violento, incluso traumático: ser amado me hace sentir directamente el espacio vacío entre lo que yo soy como un ser determinado y la $\mathrm{X}$ indescifrable en mí que causa el amor. ${ }^{23}$ (Žižek, 2009: 47-48)

Algunos pensadores de lo moral confirman indirectamente que, efectivamente, el motivo último del mandato de amar al vecino puede ni ser el obedecer una orden divina, ni siquiera el bienestar del vecino. El motivo último sería, de hecho, el propio sujeto, en una relación de dignidad del ser humano consigo mismo, en una conducta moral que se deriva de que este "no se debe contradecir a sí mismo haciendo una excepción en su propio favor, no debe colocarse a sí mismo en una posición en la que tenga que despreciarse a sí mismo"24 (Arendt, 2003: 67). Como afirma Kant, "[n]o consideraremos las

\footnotetext{
22 "We should regard all human beings as our fellow citizens and neighbors".

23 "When Freud and Lacan insist on the problematic nature of the basic Judeo-Christian injunction to 'love thy neighbour,' they are thus not just making the standard critic-ideological point about how every notion of universality is coloured by our particular values and thus implies secret exclusions; they are making a much stronger point on the incompatibility of the Neighbour with the very dimension of universality. What resists universality is the properly inhuman dimension of the Neighbour. It is for this reason that finding oneself in the position of the beloved is so violent, traumatic even: being loved makes me feel directly the gap between what $\mathrm{I}$ am as a determinate being and the unfathomable $\mathrm{X}$ in me which causes love."

24 "...must not contradict himself by making an exception in his own favour, he must not place himself in a position in which he would have to despise himself."
} 
acciones obligatorias porque son mandamientos de Dios, sino que las consideraremos mandamientos divinos porque tenemos una obligación interna hacia ellos"25 (citado en Arendt, 2003: 66). Según Arendt, "Kant, con la consistencia de pensamiento que es la marca del gran filósofo, así pues, antepone los derechos que el hombre tiene consigo mismo a sus obligaciones para con los otros [...]. El estándar no es ni el amor a un vecino ni el amor a uno mismo, sino el respeto a uno mismo"26 (Arendt, 2003: 67). Según Arendt,

[1]as poquísimas propuestas que se supone resumen todos los preceptos y mandamientos, tales como "Ama al vecino como a ti mismo", "No le hagas a los demás lo que no quisieras que te hicieran a $t i$ ” $\mathrm{y}$, finalmente, la famosa fórmula de Kant: "Obra de tal modo que la máxima de tu acción pueda convertirse en una ley general para todos los seres inteligibles", todas toman como estándar el Yo y, por lo tanto, la relación del hombre consigo mismo. En nuestro contexto, no importa si el estándar es el amor a uno mismo, como en los preceptos hebreocristianos, o el miedo al desprecio a uno mismo, como en Kant. ${ }^{27}$ (Arendt, $2003: 76$, cursiva en el original)

3. En estrecha relación con esta cuestión, Zygmunt Bauman plantea el problema de que si amar al vecino es un mandato de actuar moralmente, esa misma naturaleza de obligación de hacer exactamente lo que se nos dice lo puede convertir en un mandato absoluto que nos haga irresponsables, más que responsables, y que, integrado en la ideología prevalente, nos prive de cualquier posible agentividad en cuanto a la obediencia o no al mismo. Como señala Laura López,

[e]n su análisis de los argumentos del filósofo Knud Ejler Løgstrup sobre la 'exigencia ética', Bauman apunta: "Si nos dijeran exactamente qué hacer, 'la sabiduría, las percepciones y el amor con el que debemos actuar' ya no serían 'nuestros', el mandato no sería una llamada a la

\footnotetext{
25 "We shall not look upon actions as obligatory because they are the commands of God, but shall regard them as divine commands because we have an inward obligation to them."

26 "Kant, with the consistency of thought which is the mark of the great philosopher, therefore puts the duties man has to himself ahead of the duties to others [...] The standard is neither the love of some neighbour nor self-love, but self-respect."

27 "The very few moral propositions which supposedly sum up all special precepts and commands, such as 'Love thy neighbor as thyself,' 'Don't do unto others what you don't want to be done to yourself,' and, finally, Kant's famous formula: 'Act in such a way that the maxim of your action can become a general law for all intelligible beings,' all take as their standard the Self and hence the intercourse of man with himself. In our context it does not matter whether the standard is self-love, as in the Hebrew-Christian precept, or the fear of self-contempt as in Kant."
} 
humanidad, a la imaginación y a las percepciones, - sino a la obediencia; la ética cristiana, en particular se vería 'osificada en ideología' (The Individualized Society 2001: 170).” 28 (López)

4. La crítica a la falta de agentividad en la obligación de obediencia al mandato ha ido acompañada de otra crítica, de naturaleza distinta, que se refiere a la motivación de esa ciega obediencia. Esta cuarta objeción apunta a que la obediencia no se deba solo al respeto a la voluntad divina y tal vez la obediencia al precepto no se deba tampoco al acatamiento prácticamente absoluto a la ideología imperante. Tal vez responda al mismo hecho de la vulnerabilidad humana $y$, en concreto, a nuestra consciencia de nuestra precariedad, de la vulnerabilidad del otro y de la amistad entre los dos basada en la "base de la comunicación;" en el saber la ausencia del otro en su muerte mientras el otro vive (Blanchot, 1988: 25), en el ser consciente de la presencia de su "eterna e insoportable ausencia” en la misma vida, sólo en compañía de la -quizás podríamos añadir en vecindad a la- cual podemos "encontrarnos con nuestra propia soledad” (Blanchot, 1988: 25). Roberto Esposito señala que

[1]o que nos une en la misma "comunidad de destino", en un futuro comunal, es el hecho de ser morituri. [...] Lo que esto significa es que la comunidad humana está en contacto cercano con la muerte, "una sociedad de y con la muerte". [...] Sin embargo, Agustín dice algo más que nos introduce en la percepción moderna, hobbesiana de la comunidad: el amor al vecino es directamente proporcional a la memoria de un peligro común (communis periculi) que compartimos. Si la comunidad de pecado en la cual tenemos nuestro origen está marcada por el miedo, nadie puede estar seguro en esta vida, que está literalmente sitiada por la muerte. ${ }^{29}$ (Esposito, 2010: 11-12)

5. Otra fuente de objeciones importantes a la orden de amar al vecino radica no ya en las motivaciones del amor sino en las características requeridas del

\footnotetext{
28 "In his analysis of philosopher Knud Ejler Løgstrup's arguments on the 'ethical demand', Bauman notes: "Were we told exactly what to do, 'the wisdom, insight, and love with which we are to act' would 'no longer be our own'; the command would not be a call to humanity, imagination and insight — but to obedience; Christian ethics, in particular, would be 'ossified into ideology".

29 'What joins us in the same 'community of destiny,' in a communal future, is our being morituri. [...] What this means is that the human community is in close contact with death, 'a society from and with the dead.' [...] Yet Augustine says something else that introduces us into the modern, Hobbesian, perception of community: the love for one's neighbour is directly proportional to the memory of common danger (communis periculi) that we share. If the community of sin from which we originate is marked by fear, no one can be secure in this life, which is literally besieged by death)."
} 
objeto de amor. ¿Debemos amar al vecino porque está cerca y, por lo tanto, suponemos, nos es cercano en algún sentido más que físico? ¿Debemos amar al vecino más que a quien no es vecino? ¿Debemos amar al vecino y no a quien no es vecino? Slavoj Žižek, en este sentido resulta, como frecuentemente, tan controvertido y polémico como estimulante:

¿No resulta extraño que el mismo soldado que masacró a civiles inocentes estuviera dispuesto a sacrificar su vida por su comando? ¿Que el comandante que ordenó la ejecución de los rehenes pueda esa misma noche escribir una carta a su familia llena de amor sincero? Esta limitación de nuestra preocupación ética a un círculo estrecho parece ir en contra de nuestra percepción espontánea de que todos somos humanos, con las mismas esperanzas, los mismos miedos y los mismos sufrimientos y, por lo tanto, con la misma reivindicación justificada de respeto y dignidad. Consecuentemente, aquellos que limiten el ámbito de su preocupación ética son, en sentido profundo, inconsistentes, incluso "hipócritas". Poniéndolo en términos habermasianos, están implicados en una contradicción pragmática, ya que violan las normas éticas que sostienen a su propia comunidad de habla. Negarles los mismos derechos éticos básicos a aquellos que están fuera de nuestra comunidad que a aquellos dentro de ella es algo que no le surge de manera natural a un ser humano. Es una violación de nuestra inclinación ética espontánea. Implica una represión brutal y la negación de uno mismo. ${ }^{30}$ (Žižek, 2009: 41)

6. Una objeción más al precepto proviene del hecho de que "el vecino" pueda ser contemplado exclusivamente en cuanto objeto o destinatario de nuestro amor pero no como agente, emisario, a su vez, de amor a su vecino (yo y/o, especialmente, otros que no son yo). La falta de contextualización del objeto de nuestro amor aparece como problema, por ejemplo, en el pensamiento de Emmanuel Levinas, quien aportó mayor complejidad a la discusión sobre el vecino al recordarnos que aunque se trate de un Otro, éste (el vecino) es un Otro

\footnotetext{
30 "Isn't it strange that the same soldier who slaughtered innocent civilians was ready to sacrifice his life for his unit? That the commander who ordered the shooting of hostages can that same evening write a letter to his family full of sincere love? This limitation of our ethical concern to a narrow circle seems to run counter to our spontaneous insight that we are all humans, with the same basic hopes, fears and pains, and therefore the same justified claim to respect and dignity. Consequently, those who constrain the scope of their ethical concern are in a profound sense inconsistent, 'hypocritical' even. To put it in Habermasian terms, they are involved in a pragmatic contradiction, since they violate the ethical norms which sustain their own speech community. Refusing the same basic ethical rights to those outside our community as to those inside it is something that does not come naturally to a human being. It is a violation of our spontaneous ethical proclivity. It involves brutal repression and self-denial."
} 
con otros; de hecho, la relación con el vecino no es puramente o solamente recíproca, sino que tiene lugar en la comunidad, la cual, necesariamente, va a afectar esa relación que, en la teoría del precepto, es de uno a uno:

[...] se trata del hecho de la multiplicidad de los hombres y de la presencia de alguien más al lado del Otro, lo cual condiciona las leyes y establece justicia. Si estoy solo con el Otro, le debo todo; pero hay alguien más. ¿Sé qué es mi vecino en relación con otra persona? ¿Sé si alguien más tiene un entendimiento con él o con su víctima? ¿Quién es mi vecino? Es consecuentemente necesario sopesar, pensar, juzgar, al comparar lo incomparable. ${ }^{31}$ (Levinas, 2011: 90)

7. Continuando con el listado de objeciones, debemos referirnos al que cuestiona no solo la naturaleza exacta del "amor" al que se refiere el precepto ni tampoco a quién nos referimos por "el vecino", sino que examina concretamente el requisito de que el amor al vecino sea como a uno mismo. Si amar al vecino es un precepto, el precepto resulta ser doble, pues requiere también del amor a uno mismo, del amor propio. En este sentido, Zygmunt Bauman, uno de los teóricos que enfatiza la bondad del precepto, no puede evitar reconocer su potencial problema estructural, que es que "implícitamente presupone el amor propio como algo que está siempre ya ahí y que nos ha sido conferido, sin problema"32 (2003: 78). Para Bauman, el amarse a uno mismo no es algo que venga dado, sino que solo sucede en el caso de que se hayan producido unas circunstancias concretas:

[...] lo que amamos en nuestro amor a uno mismo es el yo que puede ser amado. Lo que amamos es el estado, o la esperanza, de ser amados. De ser objetos merecedores del amor, de ser reconocidos como tales, y de que nos den la prueba de ese reconocimiento.

En resumen: para poder tener amor a uno mismo, necesitamos ser amados. La negación del amor - el hecho de que se nos niegue el estatus de objeto merecedor del amor- genera auto-odio. El amor a uno mismo se construye en base al amor que nos han ofrecido los otros. [...]

\footnotetext{
31 " [...] it is the fact of the multiplicity of men and the presence of someone else next to the Other, which condition the laws and establish justice. If I am alone with the Other, I owe him everything; but there is someone else. Do I know what my neighbor is in relation to someone else? Do I know if someone else has an understanding with him or his victim? Who is my neighbor? It is consequently necessary to weigh, to think, to judge, in comparing the incomparable."

32 "implicitly casts self-love as un-problematically given, as always-already there".
} 
Otros nos deben amar primero para que podamos empezar a amarnos a nosotros mismos. ${ }^{33}$ (Bauman, 2003: 80)

¿Cómo podemos saber que somos amados? Bauman sostiene que "[1]o sabemos, creemos que lo sabemos, y nos sentimos seguros de que esa creencia no es errónea, cuando nos hablan y nos escuchan. Cuando nos escuchan con atención, con un interés que revela/señala una disposición a responder a lo que decimos. Entonces intuimos que somos respetados. Suponemos, eso es, que lo que pensamos, lo que hacemos, o lo que nos proponemos hacer -importa" ${ }^{34}$ (Bauman, 2003: 80).

En resumen, así pues, solo puedo amar al vecino si me amo a mí mismo, y solo puedo amarme a mí mismo si he sido escuchado y tenido en cuenta en mi condición de ser único. Únicamente en el caso de que se reúnan todas estas circunstancias - no pocas- entonces "[e]l amor a nuestros vecinos como nos amamos a nosotros mismos significará, así pues, que respetaremos el ser único del otro - el valor de nuestras diferencias que enriquece el mundo que habitamos conjuntamente y, de este modo, lo hará un lugar más fascinante y placentero y se sumará a la cornucopia de sus promesas"35 (Bauman, 2003: 81, cursiva en el original).

\section{El precepto (y, de hecho, el vecino mismo), en conclusión, como problema}

Este listado - altamente incompleto, nos tememos- de objeciones al precepto, objeciones de naturaleza tanto teórica como práctica, fue tal vez anticipado ya por Sigmund Freud en El malestar en la cultura con su pregunta retórica de cómo era posible que las grandes religiones monoteístas coincidieran en exigir algo no sólo imposible, sino también/incluso irracional. Partiendo de Freud, los teóricos Slavoj Žižek, Eric L. Santner y Kenneth Reinhard coinciden en que:

\footnotetext{
33 "what we love in our self-love is the selves fit to be loved. What we love is the state, or the hope, of being loved. Of being objects worthy of love, being recognized as such, and given the proof of that recognition. In short: in order to have self-love, we need to be loved. Refusal of love -denial of the status of a love-worthy object- breeds self-hatred. Self-love is built out of the love offered to us by others. [...] Others must love us first, so that we can begin to love ourselves."

34 "We know it, we believe that we know it, and we are reassured that the belief is not mistaken, when we are talked to and listened to. When we are listened to attentively, with an interest that betrays / signals a readiness to respond. We gather then that we are respected. We suppose, that is, that what we think, do, or intend to do -counts."

${ }_{35}$ "Loving our neighbours as we love ourselves would mean then respecting each other's uniqueness - the value of our differences that enrich the world we jointly inhabit and so make it more fascinating and enjoyable a place and add further to the cornucopia of its promises."
} 
[a] los lectores escépticos, tanto religiosos como seculares, el mandamiento de amar al vecino no les ha parecido nada racional y, de hecho, les ha resultado profundamente enigmático - ciertamente, como un enigma que nos obliga a repensar la misma naturaleza de la subjetividad, de la responsabilidad y de la comunidad. Podríamos incluso afirmar que el amor al vecino no es una ley que pueda ser obedecida literalmente, ni tampoco una ley que pueda ser ejemplificada de manera cierta, sino una regla que sólo puede ser confirmada mediante su excepción. Es decir, el amor al vecino funciona más como un obstáculo a su propia teorización que como una hoja de ruta a la vida ética. (5)

Žižek no solo asegura que el vecino, "con toda la carga judeo-cristianafreudiana de este término [...] no importa cuán lejos esté físicamente, siempre está por definición 'demasiado cerca'”36 (Žižek, 2009: 38), sino que cuestiona radicalmente el precepto de amarle al señalar que, más que generar nuestro amor, el vecino puede, de hecho, generar nuestra violencia por el mero hecho de su presencia. En el capítulo dos de su volumen Violence, que lleva por título el interesante "Allegro moderato - Adagio. Fear thy neighbor as thyself!" (¡Teme al vecino como a ti mismo!), Žižek enfatiza esta potencialidad negativa del vecino:

[d]ado que el Vecino es, como Freud sospechó hace ya mucho tiempo, primordialmente una cosa, un intruso traumático, alguien cuyo modo de vida diferente al nuestro (o, mejor dicho, cuyo modo de jouissance materializado en sus prácticas sociales y rituales) nos molesta, hace que descarrile nuestro modo de vida cuando se acerca demasiado, esto puede también generarnos una reacción agresiva con el objetivo de librarnos de ese intruso molesto. ${ }^{37}$ (2009: 50)

En 2005 Žižek había argumentado, desde una perspectiva psicoanalítica, que ya desde el Antiguo Testamento el judaísmo nos había abierto "una tradición en la cual una semilla traumática de lo ajeno persiste siempre en mi Vecino - el Vecino sigue siendo una presencia inerte, impenetrable, enigmática, que me histeriza. El núcleo de esa presencia, por supuesto, es el deseo que siente el Otro,

\footnotetext{
36 "with all the Judeo-Christian-Freudian weight of this term [...] no matter how far away it is physically, is always by definition 'too close'."

37 "Since a Neighbour is, as Freud suspected long ago, primarily a thing, a traumatic intruder, someone whose different way of life (or, rather, way of jouissance materialized in its social practices and rituals) disturbs us, throws the balance of our way of life off the rails, when it comes too close, this can also give rise to an aggressive reaction aimed at getting rid of this disturbing intruder." (50)
} 
un enigma no solo para nosotros, sino también para el propio Otro"38 (Žižek, 2006: 140-141).

La historia occidental reciente imposibilita que seamos ingenuos en nuestra evaluación de las potencialidades de la vecindad. Por desgracia, si tenemos en cuenta los acontecimientos históricos que han tenido lugar en las décadas entre la publicaciones de los textos de Freud y los de Žižek, y justamente, por ejemplo, en las regiones de Europa desde donde los escribieron, solo podemos concluir esta sección en el tono amargo que resulta de la ecuación entre "presencia del vecino" y "violencia hacia el vecino". La convivencia entre vecinos alemanes no judíos y alemanes judíos en un estado-nación a lo largo del siglo XIX no resultó en amor, sino en un genocidio. Y, como afirmaba Tony Kushner en 1993, en relación con el conflicto balcánico,

[n]o creo que la falta de contacto con otras culturas sea el origen en sí misma de las brutales formas de odio que resultan en violencia. Y el contacto tampoco garantiza la Tolerancia. En las comunidades de lo que era antes Yugoslavia las culturas diferentes que vivían en la mayor de las intimidades posibles, incluyendo matrimonios mixtos, escuelas $y$ viviendas integradas, se han dividido en facciones antagónicas, y los serbios están ahora masacrando a musulmanes bosnios que habían sido los vecinos de la puerta de al lado. ${ }^{39}$ (Kushner, 1993: 45)

\section{Contextualizando a "el vecino" en el siglo XIX}

Es necesario contextualizar a "el vecino" puesto que cualquier implementación en la vida real del abstracto precepto "ama al vecino como a ti mismo" supone una interacción entre el sujeto y su vecino que tiene lugar, como afirma Judith Butler, dentro de un marco social:

Al formular la pregunta ética "Cómo debería tratar a otro?" estoy inmediatamente atrapada en el ámbito de la normatividad social, ya que el otro solamente se me aparece, solo funciona como otro para mí, si existe un marco dentro del cual puedo ver y aprehender al otro en su

\footnotetext{
38 "opens up a tradition in which an alien traumatic kernel forever persists in my Neighbor the Neighbor remains an inert, impenetrable, enigmatic presence that hystericizes me. The core of this presence, of course, is the Other's desire, an enigma not only for us, but also for the Other itself."

39 "I do not believe that a lack of exposure to other cultures in and of itself breeds the virulent forms of hatred that lead to violence. Nor does exposure guarantee Tolerance. In the communities of what was formerly Yugoslavia, different cultures living in the greatest intimacy possible, including intermarriage, integrated schools and housing, have split into stark factions, and the Serbs are now massacring Bosnian Moslems who were formerly next-door neighbors."
} 
separación y exterioridad. Así que, aunque yo pueda pensar en la relación ética como diádica o incluso como presocial, estoy atrapada no solo en la esfera de la normatividad sino en la problemática del poder cuando planteo la pregunta ética directamente y en su simplicidad: "Como debería tratarte?" Si el "yo" y el "tú" deben primeramente llegar a ser, y si un marco normativo es necesario para esta aparición y este encuentro, entonces las normas funcionan no solo para dirigir mi conducta sino para condicionar la posible aparición de un encuentro entre mí misma y el otro. ${ }^{40}$ (Butler, 2005: 25)

La voluntad del presente dossier es analizar la interacción entre el sujeto y su vecino en lo social, en el marco concreto de occidente y de la modernidad, época que nos obliga a tener en cuenta dos nociones clave, nación y estado, puesto que, como indica Hannah Arendt,

[1]a distinción entre una esfera pública y una privada de la vida se corresponde con los ámbitos domésticos y con los políticos, los cuales han existido como entidades distintas y separadas por lo menos desde la emergencia de la ciudad-estado en la antigüedad; pero la aparición del ámbito social, que no es privado ni público, hablando estrictamente, es un fenómeno relativamente nuevo cuyo origen coincide con la aparición de la edad moderna y que encontró su forma política en el estadonación. ${ }^{41}$ (Arendt, 1998: 28)

Desde la modernidad, entendemos que "el colectivo de familias organizadas económicamente en el facsímil de una familia super-humana es lo que

\footnotetext{
40 "In asking the ethical question 'How ought I to treat another?' I am immediately caught up in a realm of social normativity, since the other only appears to me, only functions as an other for me, if there is a frame within which I can see and apprehend the other in her separateness and exteriority. So though I might think of the ethical relation as dyadic or, indeed, as presocial, I am caught up not only in the sphere of normativity but in the problematic of power when I pose the ethical question in its directness and simplicity: 'How ought I to treat you?' If the 'I' and the 'you' must first come into being, and if a normative frame is necessary for this emergence and encounter, then norms work not only to direct my conduct but to condition the possible emergence of an encounter between myself and the other."

${ }_{41}$ "The distinction between a private and a public sphere of life corresponds to the household and the political realms, which have existed as distinct, separate entities at least since the rise of the ancient city-state; but the emergence of the social realm, which is neither private nor public, strictly speaking, is a relatively new phenomenon whose origin coincided with the emergence of the modern age and which found its political form in the nation-state."
} 
denominamos 'sociedad', y su forma política de organización la denominamos 'nación'”42 (Arendt, 1998: 29).

\section{Vecino y nación en el diecinueve}

El análisis de las construcciones (y destrucciones) de las políticas comunitarias en occidente, como demuestra la anterior cita, nos pide, a su vez, que prestemos atención al siglo de "antiguas comunidades idílicas, [...] primitivas 'sociedades orgánicas' que existe solamente en la imagerie romántica del siglo diecinueve" 43 (Esposito, 2010: 12). El diecinueve consolida el vínculo entre sujeto-familiacomunidad (de vecinos) y estado-nación del que habla Hannah Arendt:

[... del mismo modo en que la unidad familiar había sido identificada con un trozo de tierra poseído privadamente (su propiedad), la sociedad era identificada con un trozo de tierra tangible pero poseído colectivamente, el territorio del estado-nación que, hasta su declive en el siglo veinte, les ofreció a todas las clases un substituto a la casa de propiedad privada que a la clase de los pobres le había sido negada. Todas las teorías orgánicas del nacionalismo, especialmente en su versión centroeuropea, se basan en la identificación de la nación y de las relaciones entre sus miembros con la familia y las relaciones familiares. Dado que la sociedad se convierte en el substituto de la familia, se supone que "la sangre y la tierra" van a dirigir las relaciones entre sus miembros: la homogeneidad de la población y su arraigo en la tierra de un territorio dado se convierten en los requisitos del estado-nación en todas partes. Sin embargo, mientras su desarrollo sin duda mitigó la crueldad y la pobreza, apenas tuvo repercusión en el proceso de expropiación y de alienación mundial, ya que el concepto de propiedad colectiva, hablando estrictamente, es una contradicción en sí mismo. ${ }^{44}$ (Arendt, 1998: 256)

\footnotetext{
42 "the collective of families economically organized into the facsimile of one super-human family is what we call 'society,' and its political form of organization is called 'nation."'

43 "former idyllic community, [...] primitive 'organic society' that exists only in the Romantic imagerie of the nineteenth century."

44 "just as the family unit had been identified with a privately owned piece of the world, its property, society was identified with a tangible, albeit collectively owned, piece of property, the territory of the nation-state, which until its decline in the twentieth century offered all classes a substitute for the privately owned home of which the class of the poor had been deprived. The organic theories of nationalism, especially in its Central European version, all rest on an identification of the nation and the relationships between its members with the family and family relationships. Because society becomes the substitute for the family, 'blood and soil' is supposed to rule the relationships between its members; homogeneity of population and its
} 
En el diecinueve tuvo lugar la consolidación del concepto de "comunidad nacional", a causa de numerosos movimientos identitarios nacionalistas románticos y de cambios estructurales en la realineación de los pueblos dentro de nuevos espacios geopolíticos en procesos de reestructuración de naciones y de su conversión, con mayor o menor justificación política, lingüística, religiosa, étnica o de tradición, en estados-nación, mayoritariamente vigentes hasta la actualidad. En el entorno europeo, concretamente, el siglo XIX es, en palabras de Benedict Anderson, el siglo de los "nacionalismos más nuevos que, entre 1820 y 1920, cambiaron la superficie del Viejo Mundo"45 (Anderson, 2010: 67). Concretamente, destacan los “movimientos nacionales 'de segunda generación', los desarrollados en Europa entre alrededor de 1815 y 1850"46 (Anderson, 2006: 194-195). El diecinueve es el siglo en el que las clases burguesas promueven la impresión y la difusión de novelas "nacionales" y es también el siglo de la consolidación de los periódicos de ámbito "nacional"47 que se dirigen a una comunidad en el idioma propio de la nación. Es también el siglo en el que las escuelas y universidades nacionales configuran consciencias nacionales dentro de estados-nación. Todos estos dispositivos explican, tal y como comenta Zygmunt Bauman sobre el trabajo de Anderson, "el misterio de la auto-identificación con una categoría más amplia de extraños desconocidos con quienes uno cree que comparte algo lo suficientemente importante como para que uno hable de ellos como un 'nosotros' del cual yo, el hablante, formo parte"48 (Bauman, 2003: 3132).

\section{Vecino "extranjero" en la nación del diecinueve}

Nación, nacionalidad, nacionalismo son "artefactos culturales" creados a finales del siglo XVIII (Anderson, 2006: 4) y consolidados en el diecinueve. Según Anderson, en este proceso de creación y consolidación la nación se imagina/es

rootedness in the soil of a given territory become the requisites for the nation-state everywhere. However, while this development undoubtedly mitigated cruelty and misery, it hardly influenced the process of expropriations and world alienation, since collective ownership, strictly speaking, is a contradiction in terms."

45 "newest nationalisms which, between 1820 and 1920, changed the face of the Old World."

46 "'second-generation' nationalist movements, those which developed in Europe between about 1815 to $1850 . "$

${ }^{47}$ La novela y el periódico (o la novela en el periódico, apareciendo en formato serializado) consolidan el rol que ya tuvieron en el siglo anterior: "[...] if we consider the basic structure of two forms of imagining which first flowered in Europe in the eighteenth century: the novel and the newspaper. For these forms provided the technical means for 're-presenting' the kind of imagined community that is the nation" (Anderson, 2006: 24-25).

48 "the mystery of self-identification with a large category of unknown strangers with whom one believes oneself to share something important enough to make one speak of them as 'we' of which I, the speaker, am a part." 
imaginada triplemente como "limitada", en tanto que rodeada de fronteras definidas, como "soberana" y como "comunidad" basada en una supuesta camaradería horizontal. Los estados del diecinueve, además, se construyen sobre la noción de un pasado inmemorial. Es necesario, así pues, formularse las preguntas: ¿qué sujetos forman parte de esos recuerdos y que sujetos se verán afectados por la amnesia de la construcción del nuevo estado?, ¿a quién incluye y a quién excluye la noción de sujeto nacional?

Del mismo modo, también se hace necesario preguntarse, en torno a esta construcción nacional, no solamente quienes serán los vecinos en la nación, sino también quienes serán los vecinos de la nación, especialmente si pensamos en la paradójica simultaneidad de la concreción y la abstracción del mapa nacional, un asunto al que Anderson se aproxima desde la concepción del mapa del estadonación y de sus colonias:

El segundo avatar fue el mapa-como-logo. Sus orígenes eran razonablemente inocentes - la práctica de los estados imperiales de colorear sus colonias en mapas con un tinte imperial. En los mapas imperiales de Londres, las colonias británicas solían ser de uno rojo rosado, las francesas azul-púrpura, las holandesas marrón amarillento, etc. Teñida de esta forma, cada colonia aparecía como una pieza separable de un puzzle. A medida que se normalizaba este efecto "puzzle", cada "pieza" podía ser separada completamente de su contexto geográfico. En su forma final, todas sus glosas explicativas podían ser eliminadas de golpe: las líneas de longitud y latitud, los nombres de lugares, las señales de ríos, mares y montañas, los vecinos. ${ }^{49}$ (Anderson, 2006: 175 , cursiva en el original)

\section{Vecino "extraño" en la ciudad del diecinueve}

El diecinueve fue también un siglo de grandes cambios en cuanto a quién era el vecino, dados los enormes movimientos migratorios desde zonas agrarias y/o rurales hacia las grandes áreas urbanas, tanto en el plano intranacional como en el internacional e incluso en el transcontinental. En las crecientes ciudades se redibujaron, así pues, no solo las relaciones entre aquellos sujetos considerables vecinos "nacionales", conocidos y desconocidos, sino entre éstos y otros

\footnotetext{
49 "The second avatar was the map-as-logo. Its origins were reasonably innocent -the practice of the imperial states of colouring their colonies on maps with an imperial dye. In London's imperial maps, British colonies were usually pink-red, French purple-blue, Dutch yellowbrown, and so on. Dyed this way, each colony appeared like a detachable piece of a jigsaw puzzle. As this 'jigsaw' effect became normal, each 'piece' could be wholly detached from its geographic context. In its final form all explanatory glosses could be summarily removed: lines of longitude and latitude, place names, signs for rivers, seas, and mountains, neighbours."
} 
considerados "extranjeros". Para Zygmunt Bauman, estas relaciones, que caracterizan, desde el diecinueve, a las ciudades, están marcadas por el miedo: "[1]os miedos actuales nacieron al brotar simultáneamente la liberalización y el individualismo, cuando ya se habían aflojado o roto los lazos de parentesco y vecindad que unían con firmeza a comunidades y corporaciones, lazos que se tenían por eternos o que al menos existían desde tiempos inmemoriales" (2006: 12). El vecino resulta, según Bauman, complicado, ya que su "presencia en nuestro campo de acción sigue produciendo incomodidad [...] Compartir el espacio con extranjeros, vivir cerca de ellos sin haberlos invitado y sufriendo su molesta presencia, es una circunstancia que a los habitantes de las ciudades se les hace muy difícil, tal vez imposible, eludir." (Bauman, 2006: 27-28). De manera muy real, en el diecinueve y, por supuesto, desde el diecinueve, el vecino puede ser alguien cuya procedencia, idioma, costumbres e idiosincrasias nos sean desconocidos. En su optimismo característico, Bauman de nuevo nos ofrece la lectura más positiva posible de esta exposición circunstancial y obligada a lo desconocido:

gracias a los inmigrantes que proceden de lugares remotos, el "choque de civilizaciones" del que habla Samuel Huntington se ha transformado de repente en un encuentro de vecinos: gente real, hombres y mujeres seguramente ataviados de forma un tanto extraña - que quizás hablan nuestra lengua con un acento horrible, con un acento impropio; que quizás puedan descansar en horas distintas a las nuestras y ser distintos en muchos aspectos, pero que, sin embargo, son seres humanos, vecinos a quienes más tarde o más temprano encontraremos en los restaurantes, en las calles, en las tiendas, en los despachos, por todas partes. (Bauman, 2006: 72)

Sin embargo, abundando en esa naturaleza circunstancial y obligada de la exposición en la convivencia, Judith Butler enuncia, en un pensar que simultáneamente proviene de Levinas y lee a Levinas contra sí mismo, "[r]esulta, en distintas formas, un ultraje ser éticamente responsable de alguien a quien uno no elige" ${ }^{50}$ (Butler, 2005: 91).

¿Resulta un ultraje tener que ser responsable de un vecino desconocido? ${ }_{i}$ Es nuestra obligación para con todo vecino, cercano o lejano, ya que, como indica Butler en trabajos posteriores basados en el trabajo tanto de Levinas como de Arendt, nadie tiene derecho a decidir con quién cohabita el planeta?

\footnotetext{
50 "It is, in some ways, an outrage to be ethically responsible for one whom one does not choose."
} 


\section{Motivaciones del dossier: Representaciones literarias del amor a "el vecino"}

Interesadas en estas preguntas, las contribuciones a este dossier estudian obras literarias relevantes de la modernidad en el mundo occidental y analizan si en ellas "el vecino" es presentado como alguien merecedor de amor dentro de la comunidad o, por el contrario, como un sujeto extraño y no merecedor de amor por no pertenecer al espacio doméstico, familiar, comunitario y/o nacional. ¿Puede el vecino en estas obras pasar de la comunidad tradicional a la comunidad afectiva de las que nos habla Maurice Blanchot?:

La primera nos es impuesta sin que tengamos libertad de elección en el asunto: es sociabilidad de facto, o la glorificación de la tierra, de la sangre, o incluso de la raza. Pero ¿y la otra? La llamamos electiva en el sentido de que existe sólo mediante una decisión que reúne a sus miembros en torno a una elección sin la cual no podría haber existido; ¿es esa elección libre? O, por lo menos, ¿es esa libertad suficiente para expresar, para afirmar el compartir que constituye la verdad de esa comunidad? ${ }^{51}$ (Blanchot, 1988: 46-47)

A estas preguntas, el presente dossier se acerca desde aquellas otras que ya citábamos al mencionar las primera objeciones al precepto de amar al vecino como a uno mismo: “¿Debemos entender al vecino como una extensión de la categoría del yo, de lo familiar y del amigo, es decir como alguien como yo a quien estoy obligado a dar tratamiento preferencial; o supone la inclusión del otro en mi círculo de responsabilidad, extendiéndose hasta el extraño, incluso hasta el enemigo?" y la consiguiente: “¿Nos pide el mandamiento que expandamos el ámbito de nuestras identificaciones o nos exige que nos acerquemos, que nos hagamos responsables de una alteridad que se mantendrá radicalmente inasimilable?" ${ }^{2}$ (Žižek et al. 2009: 6-7, citados en Arizti 2013).

\footnotetext{
51 "At the onset there is need to distinguish — with whatever difficulty - between traditional community and elective community. (The first is imposed on us without our having the liberty of choice in the matter: it is de facto sociality, or the glorification of the earth, of blood, or even of race. But what about the other? One calls it elective in the sense that it exists only through a decision that gathers its members around a choice without which it could not have taken place; is that choice free? or, at least, does that freedom suffice to express, to affirm the sharing that is the truth of this community?)."

52 "Is the neighbor understood as an extension of the category of the self, the familial, and the friend, that is, as someone like me whom I am obligated to give preferential treatment to; or does it imply the inclusion of the other into my circle or responsibility, extending to the stranger, even the enemy? [...] does the commandment call us to expand the range of our identifications or does it urge us to come closer, become answerable to, an alterity that remains radically inassimilable?"
} 
Las contribuciones al dossier tratan "el vecino" de estas preguntas no en cuanto a figura abstracta, sino en la especificidad de su corpo-realidad, en sus valencias de sexo (vecino/vecina), género (masculino/femenino, masculinizado/ feminizado) y sexualidad (sexualidades hegemónicas/sexualidades alternativas, sexualidades inculcadas/sexualidades castigadas).

Los textos estudiados en las contribuciones, pertenecientes a cánones literarios de diversos estados-nación de Euro-américa, desde los Estados Unidos a Rusia pasando por Ecuador, España y Francia, revelan que toda comunidad "tradicional" basada en la procedencia "nacional" o "regional", en criterios geográfico-políticos, o en cuestiones de "raza" o etnia, está afectada por, a la vez que afecta a, el factor, como siempre, omnipresente y omnipotente: la clase social. Este factor, como veremos, determina los afectos, desafectos, grados de autonomía y de movilidad, a y de la vecina, del vecino, dentro del concepto de comunidad nacional.

A todas las contribuciones que configuran este dossier subyace la siguiente reflexión de Žižek, que conecta las dimensiones sociológicas y filosóficas del precepto "ama al vecino como a ti mismo":

en lo que uno se debe concentrar aquí es en el significado preciso del término vecino: ¿es el "vecino" en el sentido judeo-freudiano, el vecino como portador de una monstruosa Otredad, ese vecino realmente inhumano, el mismo que el vecino que encontramos en la experiencia levinasiana del rostro del Otro? ¿No hay, en el corazón mismo del vecino inhumano judeo-freudiano, una dimensión monstruosa que está ya mínimamente "aburguesada", domesticada, una vez se le concibe en el sentido levinasiano? ¿Y si el rostro levinasiano es otra defensa más contra esta dimensión monstruosa de la subjetividad? ¿Y si debemos concebir la Ley Judía como estrictamente correlativa con este vecino inhumano? En otras palabras, ¿y si la función última de la Ley no es, en realidad, capacitarnos para no olvidar al vecino, para retener nuestra proximidad al vecino, sino, por el contrario, para mantener al vecino a una distancia apropiada, servir como una especie de muro de protección contra la monstruosidad del vecino? En resumen, la tentación que debemos resistir aquí es el "aburguesamiento" ético del vecino, la reducción de la monstruosidad radicalmente ambigua del Vecino-Cosa a un Otro como el punto abismal desde el cual emana la llamada a la responsabilidad ética. ${ }^{53}$ (Žižek, 2006: 162-163, cursiva en el original)

\footnotetext{
53 "what one should focus on here is the precise meaning of the term neighbor: is the 'neighbor' in the Judeo-Freudian sense, the neighbor as the bearer of a monstrous Otherness, this properly inhuman neighbor, the same as the neighbor that we encounter in the Levinasian experience of the Other's face? Is there not, in the very heart of the Judeo-Freudian inhuman neighbor, a
} 


\section{Las contribuciones}

El dossier se compone de seis artículos redactados en cuatro idiomas (inglés, castellano, francés y catalán), que analizan expresiones literarias de la figura del vecino en el siglo XIX en contextos tan diversos como Nueva Inglaterra, el Norte y el Sur de los Estados Unidos, Ecuador, España, Francia y Rusia.

En la primera de las contribuciones, “Melville's Carnival Neighborhood”, Wyn Kelley, desde la perspectiva de Comunidades imaginadas de Benedict Anderson, trata los Estados Unidos y la peculiaridad del concepto del vecino en ese país desde prácticamente sus orígenes. Kelley cita a Thomas Paine quien, a finales del siglo XVIII, anunciaba en El sentido común (1776) que, a diferencia de los británicos y resto de ciudadanos de diversos países europeos - quienes compartían todos ellos, en sus respectivos países, un sentido de nacionalidad común-, los americanos tenían que recordarse a sí mismos que eran vecinos y no miembros de diferentes naciones. En el núcleo de su artículo, Kelley estudia la relación entre los dos grandes novelistas del siglo XIX estadounidense, Nathaniel Hawthorne y Herman Melville, quienes, entre mayo de 1850 y noviembre de 1851, fueron vecinos relativamente cercanos en la región de los Berkshires, Massachusetts, lo cual les permitió visitarse mutuamente en numerosas ocasiones. Fue precisamente en ese periodo cuando ambos escribieron algunas de sus mejores obras, entre ellas La casa de los siete tejados (1851), en el caso de Hawthorne, y Moby-Dick (1851), en el de Melville. Y fue nada más conocerse que Melville escribió su famosa reseña sobre la obra de Hawthorne en la que anunciaba la plenitud de la literatura nacional americana al celebrar, refiriéndose a Hawthorne, que habían nacido y estaban naciendo personas con el talento de Shakespeare en aquel lado del océano. Si bien mucho se ha escrito sobre la amistad, sobre el posible enamoramiento de Melville por Hawthorne y sobre las posibles influencias literarias entre ambos, Kelley opta por estudiar el modo en que esta relación estuvo marcada por la vecindad y, en concreto, por la influencia que dentro de esa vecindad tuvo Sarah Morewood, una mujer cuyo espíritu festivo, carnavalesco e incluso subversivo quizás pudo haber conferido a la relación entre ambos escritores nuevas posibilidades de libertad y fluidez. Estas

monstrous dimension which is already minimally 'gentrified,' domesticated, once it is conceived in the Levinasian sense? What if the Levinasian face is yet another defense against this monstrous dimension of subjectivity? And what if the Jewish Law is to be conceived as strictly correlative to this inhuman neighbor? In other words, what if the ultimate function of the Law is not to enable us not to forget the neighbor, to retain our proximity to the neighbor, but, on the contrary, to keep the neighbor at a proper distance, to serve as a kind of protective wall against the monstrosity of the neighbor? In short, the temptation to be resisted here is the ethical 'gentrification' of the neighbor, the reduction of the radically ambiguous monstrosity of the Neighbor-Thing into an Other as the abyssal point from which the call of ethical responsibility emanates." 
posibilidades se verían reflejadas tanto en el vínculo personal entre ambos, especialmente en la expresión de los sentimientos de Melville por Hawthorne, como en la producción literaria de los dos. Kelley analiza en concreto las atrevidas, apasionadas y verdaderamente hermosas misivas de Melville a Hawthorne y dos obras literarias de Melville publicadas a mediados de la década de los 1850: la novela Israel Potter, en la que encontramos la intimidad de la vecindad entre su protagonista, Israel Potter, y el personaje histórico de John Paul Jones, y la colección de cuentos Las Encantadas sobre el archipiélago de las Galápagos en tanto que islas vecinas. Tanto en la correspondencia como en las piezas de ficción seleccionadas, Kelley encuentra evidencias de un concepto de vecindad subversivo en el que hay valencias de proximidad accidental, amistad, intimidad física no anticipada, erotismo y entrega, por una parte, pero también de ambigüedad, conflicto y violencia, la violencia de la que nos habla Žižek, por otra. Ello desmitifica una noción ideal y neutra de la vecindad, al tiempo que demuestra la relevancia no solo cultural, sino también política, de esa vecindad vivida entre estos dos grandes escritores canónicos que inventaron el concepto de autor literario estadounidense en los albores del movimiento literario de ese estado-nación.

En “Dressing Uncivil Neighbor(Hood)s. Walt Whitman's Adhesive Democracy in 'Calamus' and 'Drum-Taps”', Laura López Peña selecciona dos colecciones de poemas de Walt Whitman, una escrita antes y la otra después de la Guerra Civil, "Calamus" ("Cálamo" 1860) y "Drum-Taps" ("Redobles de tambor" 1865), y establece una continuidad entre los proyectos políticos de ambas colecciones. En "Calamus" Whitman elabora su concepción de la "adhesiveness", el término frenológico con el que Whitman se refiere al amor y al erotismo entre hombres, con la esperanza de que sirva como vehículo de una auténtica democracia social, de que ayude a superar las divisiones entre vecinos nacionales al norte y sur del país, e incluso de que evite la Guerra Civil que acabaría causando más de un millón de muertos y heridos entre vecinos estadounidenses. Whitman aboga por una sociedad igualitaria, basada en la amistad y el afecto viril entre hombres, que elimine las jerarquías patriarcales y neutralice las diferencias geográficas, de clase social, religión y edad entre ellos. A pesar de que el proyecto de Whitman parece ser, inicialmente, un proyecto "nacional", éste va más allá de los Estados Unidos cuando Whitman se refiere a la raza humana con voluntad transnacional y universalista e incluye a hombres de tierras lejanas considerándolos sus vecinos, sus iguales y sus potenciales amantes. En la segunda colección de poemas, "Drum-Taps", Whitman reitera su visión democrática del amor viril entre camaradas a través de la expresión de sus relaciones personales con los soldados heridos, a los que atendió en los hospitales de guerra durante diez años. En estos pabellones de hospital hombres jóvenes de todos los estados, tanto del norte como del sur, se convierten en vecinos físicos y espirituales en relaciones de afecto auténticamente democráticas. En su optimismo y energía vitalista, Whitman cree que en los Estados Unidos de 
mediados del diecinueve se puede dar un nuevo tipo de amistad igualitaria y libre desconocida en otras regiones del planeta. Según López, el hecho de que Whitman incorporase tanto "Calamus" como "Drum-Taps" al cuerpo central de su poema épico sobre los Estados Unidos, Leaves of Grass (Hojas de hierba), demuestra la centralidad del amor entre hombres en la concepción de Whitman de la democracia americana. La voluntad de Whitman de sanar políticamente a una nación a través del amor entre hombres se materializa en poemas como "Reconciliación" en el que el poeta, norteño, besa a un enemigo sureño muerto, reconociéndolo como vecino y como un hombre "divino como yo mismo".

La obra de Whitman es especialmente interesante ya que, si bien inicialmente propone la unión entre vecinos del norte y del sur en la nación, se agranda ilimitadamente al igualar a los vecinos de una nación con los de las naciones vecinas e incluso con las lejanas y remotas. Al afirmar "Y me parece que si pudiera conocer a esos hombres sentiría afecto por ellos como lo siento por los hombres en mis propias tierras / Oh, sé que seríamos hermanos y amantes, / sé que sería feliz con ellos", Whitman revela la tensión, tal vez incluso la fractura, en la idea misma de nación en los Estados Unidos del diecinueve, no solo a nivel interno (la crisis nacional estadounidense) sino en cuanto a concepto de división con respecto a otros seres humanos.

La Guerra Civil de los Estados Unidos reveló, por lo tanto, una importante brecha en la idea misma de estado-nación. Quizás convenga recordar que el Leviathan de Hobbes, según Esposito, puede ser un dios, pero que ese “deus mortalis' es una máquina cuya mortalidad se basa en el hecho de que un día puede ser destrozado por una guerra civil"54 (Schmitt, Leviathan, 94 citado en Esposito, 2010: 38). Esta “mortalidad” del gran concepto de estado-nación queda a menudo disimulada por las argucias de la historiografía. Concluimos con una cita de Anderson, que nos parece especialmente relevante al respecto de las ideas de "vecinos en la nación" y de "nación vecina":

Una industria pedagógica ingente trabaja sin descanso para obligar a los jóvenes americanos a recordar/olvidar las hostilidades de 1861-1865 como una gran guerra "civil" entre "hermanos" más que entre - como lo fueron brevemente- dos estados-nación soberanos. (Podemos estar seguros, sin embargo, de que si la Confederación hubiese triunfado en mantener su independencia, esta "guerra civil" habría sido cambiada en la memoria por algo bastante no fraternal.) ${ }^{55}$ (Anderson, 2006: 201)

\footnotetext{
54 "'deus mortalis' is a machine whose mortality is based on the fact that one day it may be shattered by civil war."

55 "A vast pedagogical industry works ceaselessly to oblige Young Americans to remember/forget the hostilities of 1861-65 as a great 'civil' war between 'brothers' rather than between - as they briefly were- two sovereign nation-states. (We can be sure, however, that if
} 
En "Una incómoda vecindad: Dolores Veintimilla y la literatura de negociación con la alteridad indígena en los Andes decimonónicos" Diego Falconí Trávez analiza la figura y la recepción de Dolores Veintimilla, autora perteneciente a la burguesía criolla ecuatoriana, nacida con la nación (1830) y de intensa actividad intelectual en Cuenca hasta su suicido a la edad de veintisiete años. La obra de Veintimilla fue minimizada e intencionalmente omitida del canon literario ecuatoriano por el régimen conservador, omisión de la que fue rescatada, en tanto que poesía trágica, por el régimen liberal, ya entrado el siglo XX. Falconí propone, desde los estudios feministas y postcoloniales, una relectura que tenga en cuenta la voluntad de incidencia publica de la obra literaria y de las cartas de Veintimilla en su momento histórico, el momento de idear la nación y sus parámetros de convivencia. La obra de Veintimilla representa a la mujer y al indígena en el sistema político y cultural, combatiendo así la visión que de la comunidad nacional hacía el varón paterfamilias criollo. Para Falconí la obra de Veintimilla supone no solo un auténtico proyecto político en su imaginar la comunidad ecuatoriana como un espacio de ciudadanía y vecindad que incluye a indígenas y mujeres, sujetos no contemplados por la mirada patriarcal criolla, sino un proyecto estratégico en su voluntad de establecer coaliciones entre mujeres e indígenas en coexistencias y vecindades que visibilizaran culturalmente la auténtica heterogeneidad andina. Veintimilla consiguió escapar, en la lectura de Falconí, del espacio privado y, al escribir sobre la alteridad y desde la solidaridad, logró incidir políticamente a favor de aquellos vecinos en la nación vulnerables e históricamente discriminados. Su obra humaniza al indígena y a la mujer, supone un encuentro de subjetividades vecinas entre unos y otros, y los reinserta conceptualmente en el centro del sistema político y cultural del ideario nacional ecuatoriano.

En “Misery, Hope and Humanity in Benito Pérez Galdós' Misericordia (1897)" María Isabel Rovira Martínez de Contrasta analiza una novela que, desde la técnica del realismo, retrata la terrible miseria del Madrid del diecinueve y cómo esta brutal pobreza incide en los cuerpos y en la condición psicológica de quienes la sufren. Si bien inicialmente la novela parece estudiar las relaciones de "vecindad" en una casa entre una sirvienta, Benina, y su "ama", Francisca Juárez, el texto se abre también al estudio de la vecindad entre Benina y un tipo de personaje al que los escritores contemporáneos a Pérez Galdós habían raramente prestado atención: los mendigos de la calle. La compasión y la empatía de Benina hacia Almudena, un joven mendigo ciego marroquí al que cuida como a un hijo, demuestran que un Galdós que había perdido la fe en la capacidad regenerativa de la política, de la economía, de las instituciones y del sistema educativo españoles del diecinueve, mantuvo la esperanza en el potencial redentor de la

the Confederacy had succeeded in maintaining its independence, this 'civil war' would have been replaced in memory by something quite unbrotherly.)" 
bondad humana en los vínculos interpersonales. El hecho de que el autor de Episodios nacionales representara este vínculo extraordinario - en términos de expectativas y de convenciones - entre Benina y su "vecino" en las calles, Almudena, a pesar de sus diferencias de nacionalidad, etnicidad, idioma, sexo y religión, resulta especialmente revelador de las indicaciones de Galdós sobre dónde reside el potencial de caridad, misericordia, altruismo, generosidad y lealtad desinteresada en el trato con el vecino dentro de la nación.

El mendigo en el caso de la novela de Galdós, es no solo un sujeto no nacional, sino que incluso, en teoría, no debería siquiera ser legalmente considerado un conciudadano, dado que la definición de ciudadanía, según las instituciones modernas, se basa en cuestiones como censo, propiedad o alquiler de vivienda, tasación, impuestos urbanos, sufragio o sistema sanitario. El texto de Rovira sobre la esperanza en la capacidad personal, en Miseriocordia, de salvar al Otro, resulta, así pues, especialmente evocador de las consideraciones sobre ética y responsabilidad de Levinas, Arendt, Butler y otros pensadores de la figura del vecino en estado de precariedad y vulnerabilidad máxima, el refugiado, la refugiada, el extranjero en situación de ilegalidad.

En "Flora Tristan: De la nécessité de faire bon accueil aux femmes étrangères" Martine Reid estudia la obra de Flora Tristan, una mujer que viajó sola física y psicológicamente en una época en la que los viajes les estaban vetados a las mujeres solas, y cuya obra está en gran medida condicionada por esas vivencias personales. Nacida en 1803, hija de una joven burguesa parisina y de un peruano casados clandestinamente en España e instalados posteriormente en París, Tristan se quedó huérfana de padre desde temprana edad, se casó a los dieciocho años, tuvo tres hijos y se separó de su marido, un hombre violento. A los treinta años, finalmente, Tristan se rebela contra las leyes nacionales, que en vez de hacer justicia se ceban con los más desprotegidos. Ella misma es hija ilegítima, dado que el matrimonio de sus padres en España no es legal en Francia. Intentando combatir su difícil situación económica, Tristan emprende un viaje sola por Francia hasta embarcarse hacia Perú, donde espera ser legalmente reconocida por su familia paterna. De este viaje resulta su obra "Peregrinaciones de una paria" (1838), en la que Tristan narra sus experiencias y sus percepciones como mujer extranjera viajando sola por Perú sin hablar el idioma. Resulta especialmente interesante que Tristan se identifique ante los demás como peruana y no como francesa, a pesar de no serlo y de reconocer no poder realmente sentirse peruana. Y más interesante resulta que Tristan, a la vuelta a su Francia natal, adopte para sí la condición psicológica de extranjera en su propio país, que refleja, con entre otros gestos, cambiando su nombre de Flore a Flora. Un segundo viaje lleva a Tristan a Londres, donde se dedica a entrevistar a inmigrantes irlandeses y judíos de otras regiones de Europa, miembros del proletariado, así como a mujeres de diversas nacionalidades en prisiones y prostíbulos británicos. El compromiso de la escritora la acerca al partido 
laborista inglés y la convierte en una de las primeras reporteras que realizan entrevistas sobre el terreno, las conclusiones de las cuales publica en sus "Paseos en Londres" (1840). Ese compromiso político, desde el socialismo, continúa para Tristan con su relación con el proletariado francés ya que, a su vuelta de Inglaterra, viaja por Francia con el propósito de unir a todas y todos los trabajadores del país dentro de un mismo movimiento. Estas experiencias vitales y de adopción llevarán a Tristan a rechazar el principio de la nacionalidad por considerarlo estrecho, mezquino y generador de todo tipo de males, tal y como afirma en sus diarios personales. Tristan es en la actualidad reconocida como pionera por sus proyectos de justicia social y de lucha por los desfavorecidos, estando quizás más canonizada dentro de la historia del socialismo que en la literatura escrita por mujeres. Reid analiza, finalmente, la obra Necesidad de dar buena acogida a las mujeres extranjeras (1835), publicada probablemente a cargo de la propia autora, que trata de la situación de las mujeres "extranjeras" que se encuentran viajando solas por Francia y/o empezando una nueva vida en ese país, especialmente, en París. Resulta especialmente interesante que por "extranjeras" Tristan se refiera tanto a las mujeres que estén escapando de sus países como a aquellas que se ven obligadas, por circunstancias, a abandonar el campo y/o a sus familias para establecerse, solas, en la gran ciudad. Unas y otras son víctimas de, entre otros factores, los grandes movimientos migratorios de los años 30 , y son también potencialmente vulnerables a la miseria, al aislamiento y a verse obligadas a ejercer la prostitución. Tristan aboga por la creación de una asociación para las mujeres extranjeras, que ella misma diseña hasta el más ínfimo detalle. Al equiparar a los dos grupos de "extranjeras" (nacionales y no) diseñando para ambos el mismo tipo de acogida que se les debe proporcionar, Tristan aboga por la ayuda a la vecina necesitada, considerando vecina tanto al sujeto nacional como al sujeto en tránsito, a la inmigrante indocumentada, a la refugiada.

El artículo de Reid evidencia que en París, que para Walter Benjamin fue la capital del siglo XIX, existían sujetos que se autodefinían como ni de esta nación ni de aquella, en una nueva categoría, resultante del abrazo consciente a/de la "impureza" con voluntad política, para la que Anzaldúa nos dio el término de la mestiza, y que apunta al deseo del pensamiento queer de romper no solo con los parámetros heteronormativos, sino especialmente con las definiciones $-\mathrm{y}$ sus consecuentes exclusiones- nacionales.

En "L'abisme en els confins d'Europa: la Rússia de Dostoievski", Carlota Surós analiza la producción literaria de Fiodor Dostoievski centrándose en el concepto de vecindad en la misma. Este concepto se desarrolla a diversos niveles concéntricos que se determinan mutuamente. En primer lugar encontramos la vecindad entre Rusia y Occidente, en concreto Europa, uno de los leitmotivs de su obra y origen de una reflexión fundamental sobre el propio pueblo ruso y su relación con el vecino en todos los sentidos. En segundo lugar encontramos la 
relación entre vecinos dentro de la comunidad nacional, escindida entre la elite (artificialmente europeizada) y el pueblo ruso. Los primeros se sienten como extranjeros incomprendidos en su propia nación y los segundos se tienen por guardianes de la tradición popular. Si Europa representa la modernidad y un tipo de libertad, también representa el materialismo, los horrores del capitalismo, el individualismo, el egoísmo, la beligerancia, el caos social, mientras que Rusia puede representar la superioridad moral, la ética del campesinado en su sentido de la comunidad, el cristianismo puro. En un tercer nivel de análisis del concepto de vecindad, Surós se acerca al tratamiento que Dostoievski hace de la ciudad de San Petersburgo, donde las relaciones entre los vecinos reflejan esas mismas tensiones entre individualismo y espíritu comunitario. La figura del hombre subsuelo y, en concreto, el personaje de Raskólnikov son utilizados por Dostoievski para explorar esas tensiones entre libertad y desarraigo. Para Dostoievski, atrapado entre estos dos polos, es necesario transitar entre ambos y sintetizar, creando un auténtico intercambio y evitando el individualismo que el capitalismo había instalado en occidente en la segunda mitad del diecinueve. A los valores positivos de Occidente (el progreso, la universalidad, la modernidad, el cosmopolitismo), hay que añadir los valores positivos rusos (la experiencia de la vida inmediata, de la cultura local, la apuesta por la hermandad y la unidad nacional). Ante el temor a fenómenos tales como la fragmentación de la nación, la ruptura de la comunidad, el aislamiento psíquico del individuo, la alienación y la soledad, el empobrecimiento masivo y la polarización clasista fruto de la modernidad, la propuesta social de Dostoievski es el retorno a la comunidad basada en el intercambio y el progreso colectivo cumpliendo las obligaciones surgidas de las relaciones con los otros, a través del amor y la kenosis.

Las seis contribuciones revelan que en diversos cánones nacionales del siglo XIX se produce una identificación entre el sujeto "nacional" y el sujeto heteropatriarcal o "neutro". Desde el centro de la nación y de la definición nacional, ese sujeto define, por oposición, qué cuerpos y realidades son catalogables como "vecinos" en la nación. La reflexión crítica sobre las definiciones de "nación", "sujeto nacional" y "vecino nacional" no provendrán, por lo tanto, del sujeto nacional "puro", sino de la mujer, del indígena, del extranjero, de la persona en tránsito, del desposeído, del mendigo, del refugiado, del vulnerable. En resumidas cuentas, del sujeto no nacional y/o no concebido como vecino, quizás por ello, finalmente, concebido como menos, o incluso como no ama-ble.

Finalizamos esta introducción confesando nuestro deseo de que este dossier contribuya a combatir el término "decimonónico" en su acepción de "anticuado", "falto de vigencia", "desfasado", "carrinclón" que le confieren tanto diversos diccionarios de la lengua castellana como el propio uso de este idioma. Fueron decimonónicos grandes proyectos de organizaciones familiares no restringidas al patrón de la familia nuclear heteronormativa, fueron 
decimonónicos grandes experimentos sociales y grandes aspiraciones universalistas utópicas, fueron decimonónicas voces de activistas y militantes disidentes que cuestionaron la nación y el concepto de sujeto nacional, y fueron decimonónicos las escritoras y los escritores cuyas obras a continuación analizamos y que abogaron por la inclusión de sujetos extranjeros, vulnerables, diferentes, en la categoría de "vecino", "vecina" a quienes debemos, si sabemos, amar.

\section{REFERENCIAS BIBLIOGRÁFICAS}

Anderson, Benedict (2006), Imagined Communities, Londres, Verso.

Arendt, Hannah (1998), The Human Condition, Chicago, The University of Chicago Press.

-(2003), Responsibility and Judgment, Nueva York, Schocken Books.

Arizti Martín, Bárbara (2013), "New Possibilities of Neighbouring: Tim

Winton's Cloudstreet", Coolabah 10, Observatori: Centre d'Estudis Australians, Australian Studies Centre, Universitat de Barcelona. http://www.ub.edu/dpfilsa/coola101arizti.pdf

Bauman, Zygmunt (2001), The Individualized Society, Cambridge, Polity.

-(2003), Liquid Love. On the Frailty of Human Bonds, Cambridge, Polity.

-(2006), Confianza y temor en la ciudad. Vivir con extranjeros, trads. Josep Sampere y Enric Tudó, Barcelona, Arcadia.

Blanchot, Maurice (1988), The Unavowable Community, trad. Pierre Joris, Barrytown, Station Hill.

Butler, Judith (2005), Giving an Account of Oneself, Nueva York, Fordham University Press.

Cohen, Richard A. (2008), “Translator's Introduction”, Time and the Other, Pittsburgh, Duquesne University Press: 1-27.

Eagleton, Terry (2004), After Theory, Nueva York, Basic Books.

Esposito, Roberto (2010), Communitas. The Origin and Destiny of Community, trad. Timothy Campbell, Stanford, Stanford University Press.

Kushner, Tony (2007), "Some Questions about Tolerance", Thinking About the Longstanding Problems of Virtue and Happiness (Essays, a Play, Two Poems and a Prayer), Nueva York, Theatre Communication Group: 41-47.

Laclau, Ernesto (1992), "Universalism, Particularism, and the Question of Identity", October 61, The Identity in Question: 83-90.

Levinas, Emmanuel (2006), Humanism of the Other, Urbana, Universtiy of Illinois Press.

-(2008), Time and the Other, Pittsburgh, Duquesne University Press.

-(2011), Ethics and Infinity, Pittsburgh, Duquesne University Press. 
López, Laura (en prensa), Beyond the Walls-Potentiality Aborted. The Politics of Intersubjective Universalism in Herman Melville's Clarel.

Nussbaum, Martha (1996), "Patriotism and Cosmopolitanism", For Love of Country. Debating the Limits of Patriotism, eds. Martha C. Nussbaum y Joshua Cohen, Boston, Beacon Press: 3-17.

Reinhard, Kenneth (2006), "Toward a Political Theology of the Neighbor", The Neighbor: Three Inquiries in Political Theology, eds. Slavoj Žižek, Eric L. Santner, y Kenneth Reinhard, Chicago, University of Chicago Press: 11-75.

Rosenzweig, Franz (1985), The Star of Redemption, trad. William Hallo, Notre Dame, University of Notre Dame Press.

Santner, Eric L (2006), "Miracles Happen: Benjamin, Rosenzweig, Freud, and the Matter of the Neighbor", The Neighbor: Three Inquiries in Political Theology, Slavoj Žižek, Eric L. Santner, y Kenneth Reinhard (eds.), Chicago, University of Chicago Press: 76-133.

Sennett, Richard (2003), "Compassion Which Wounds", Respect in a World of Inequality, Nueva York, W.W. Norton \& Company: 138-139.

Žižek, Slavoj (2006), "Neighbors and Other Monsters: A Plea for Ethical Violence", The Neighbor: Three Inquiries in Political Theology, eds. Slavoj Žižek, Eric L. Santner y Kenneth Reinhard, Chicago, University of Chicago Press: 134-190.

-(2009), “Allegro moderato - Adagio. Fear thy Neighbor as Thyself!", Violence, Londres, Profile Books: 34-62.

Žižek, Slavoj, Eric L. Santner, y Kenneth Reinhard (eds.) (2006), The Neighbor: Three Inquiries in Political Theology, Chicago, University of Chicago Press. 